\title{
Positive Effects of Gossiping at Work
}

\author{
Rasha Ali Mueed Alshehre \\ University of Colorado Boulder, USA \\ Email: Raal8608@colorado.edu
}

How to cite this paper: Alshehre, R.A.M. (2017) Positive Effects of Gossiping at Work. Open Journal of Medical Psychology, 6, 126-132.

https://doi.org/10.4236/ojmp.2017.62010

Received: January 142017

Accepted: April 18, 2017

Published: April 21, 2017

Copyright $\odot 2017$ by author and Scientific Research Publishing Inc. This work is licensed under the Creative Commons Attribution International License (CC BY 4.0).

http://creativecommons.org/licenses/by/4.0/

c) (i) Open Access

\begin{abstract}
Imagining the situation: twenty office-workers stay the whole day together but they cannot gossip at work. They work a day, a week, a month, and suddenly, their productivity and work spirit lowers, they begin to fall ill and refuse to work. The reason is obvious-they miss gossiping. People like to discuss other people's lives; moreover, they cannot live without it. Moreover, if a person reveals his or her thoughts and ideas about something personal, he/she feels better, and it stimulates such a person to work better. On the contrary, when people keep too many secrets in memory and do not share them with anyone, they can fall into depression. It is doubtful whether any business owner wants to have depressive workers. In order to analyze the problem, one should consider that gossiping is a necessary type of communication at work, can benefit the working place in many effective ways, form the good atmosphere at work. Encouraging of positive gossiping can also bring efficient results into the working process.
\end{abstract}

\section{Keywords}

Gossip, Rumor, to Spread, Work, Employees, Process

\section{Introduction}

People cannot live without gossiping. Almost everyone gossips or has ever gossiped about some persons or any other themes of interest. However, many people consider gossiping to be a negative phenomenon, which influences their lives in a bad way. Since ancient times, gossipers were punished for their rumors and were even marked with some sings or other objects so that everyone knew that they spread rumors.

For example, in England, such people had to wear big iron masks on their heads, which were made to keep their mouths shut and prevent them from gossiping. Today, the situation is different, and no one marks the gossipers. Nevertheless, they are still disliked by most of the people. In many cases, such people 
are right-no one wants to be under discussion of other individuals, especially if such discussions are false slanders.

The workers, who are not allowed to gossip at work, feel lonely and useless. According to Solomon (2014) [1], "Depression is a disease of loneliness". Gossips can cure this disease since they make people closer. Thus, it is time to act and change the situation, encouraging office workers to gossip at work since it can positively affect their productivity. By taking into consideration the recent studies, one must admit that gossiping has the positive effect on the office workers, which is the reason for business owners to reconsider their views of this social phenomenon. Gossiping can make people feel closer to each other at work, raise the level of some kinds of trust among them and in the same way, to improve their cooperation together as they can share not only rumors in the working circle, but also some ideas or thoughts that can significantly improve the working process. Negative and positive gossiping can help the person to become better.

The following abstracts show that the problem of gossip is not a problem, and the negative perception people have when the word "gossip" is pronounced should be eliminated from the society. This paper is meant to show that gossiping is not as bad as it looks like, and to make people understand that gossip can be a solution to be the biggest employees' problem-stress at work. Gossip can be used as a way to interact within a working group; people must understand that gossip has its pros and cons, which can be used in a negative or positive way in order to create a better atmosphere at work, improve social skills and job results or point out trustworthy people in the team.

\section{Benefits of Gossiping at Work}

Gossiping can benefit business owners in different ways. Firstly, gossiping helps office workers to free themselves from a burden of daily routine and personal problems. Moreover, if a person speaks about some other individual, he or she will distract from daily issues or negative aspects and switch the attention to another subject. Of course, some people may argue that gossip is bad for those who are under discussion. It is true but only if gossip turn into bullying and ostracism.

Chua and Uy in their research paper "The Psychological Anatomy of Gossip" (2014), state that "The structure of the gossip episode includes support" (qtd. In Chua) [2]. The authors pay attention to the fact that a gossip only exists when there are people that appreciate sharing it. The spread of the gossip is more about the feedback it gets from the group it is shared with, rather than the content itself or the deepness of the information. The life of gossip lasts as much as the social supports that it gets. In its turn, the social support means any type of communication within the coworkers, such as explanation, assistance, distribution or call. Such interaction at a work place helps the working process to go faster and forces the employees to share the result and the effort placed at the accomplishments of the tasks that also work as the motivation.

However, if people work in a team, it is hardly possible to avoid gossiping. 
According to the researcher at Stanford University, Dr. Matthew Feinberg (2014), "Groups that allow their members to gossip sustain co-operation and deter selfishness better than those that don't" (qtd. in Prynne) [3]. The researcher means that if a person notices something unusual in the behavior of his or her co-worker (these changes are mostly negative), he or she will warn the other coworkers in order to prevent them from mistreatment or fraud. Such gossips also help to find out whether a person is selfish or not because if he/she wants to warn the others about possible problems, such a person will be a great and cooperative employee, which is always good for the employer.

\section{Gossiping Forms Good Atmosphere at Work}

Gossiping plays an important role in forming friendly atmosphere at work. It helps people to keep abreast of the important news, keep up with politics and fashion, and be aware of some personal characteristics of their co-workers. Moreover, it is an essential part of culture since it makes human society "as we know it possible" (Beck, 2014) [4]. A psychologist Robin Dunbar claims that gossiping helped to form language in society (Beck, 2014) [4]. When people spread rumors about each other, they observe some right or wrong actions of other individuals and learn by that experience. Business owners can apply this fact to educate their employees and make their work more efficient and productive. For instance, they can observe the work of other establishments and their errors and will not repeat the same failures. Thus, gossiping helps to avoid some mistakes and prevent negative consequences of some actions.

In order to prove, that gossip helps to obtain good working atmosphere at work the group of psychologists conducted several experiments, in which more than four hundred people took part. They had to observe two players who played a game. One of them cheated intentionally and won. The heart rates of the observers increased because they did not like the player who cheated. When they got a chance to warn the next players of a cheater, their heart rates lowered since the participators were glad to help the next player. The further experiments showed that people were ready to give their money in order to provide the next player a hint about the fraud.

Social psychologist Robb Willer (2012), who conducted this research, states, "The more generous and moral among us are most likely to pass on rumors about untrustworthy people, and they report doing so because they are concerned about the well-being others" (qtd. in Song) [5]. People feel unfairness and think that it is their goal to warn other people of such unfairness. Thus, they are doing a good thing and benefit society. In this case, gossiping helps them to prevent frustration and high heart rate of other people. The same happens with the office workers: when they notice something unusual and unfair, they can warn their co-workers, and their teamwork will become more cohesive, which will benefit the employer and help the team to create good working atmosphere.

Many positive rumors help people to become more self-confident at work, to discover an untrustworthy person, or just to free them from a burden of negative 
news. Gossips bring people together and define who works for a team and who is a selfish individual, which helps the employer to regulate the staff and its efficiency. Therefore, gossiping can be a very useful instrument at work for the employers since it can direct their team workers to the right course and help them to identify dishonest employees.

The theory, as any other one is not the greatest one. Trying to start a solid decent relationship with gossip and talking behind someone's back is not the best way to communicate and build trust. In some way, the theory is not perfect because the relationship based on gossip within a group might not be as tough as a relationship based on trust. Nevertheless, gossip can be a used as an innocent way to start communicating with a coworker and later on build a solid trustworthy relationship. Gossip can be used as a way to ask if anybody else faces a similar problem, to check if some certain situation is adequate and easy to fight with. All in all, gossip can form a good atmosphere at work and, used in a negative or positive way, can change the worker to the better.

\section{Negative and Positive Gossiping Helps the Worker to Become Better}

In addition, both positive and negative gossiping may be helpful for a person at work. According to the research that was conducted at the University of Groningen, Netherlands, hearing positive stories helps people to improve their personal skills, and hearing negative stories helps them to become more competent at work in order to avoid being a victim of gossiping (Zabell, 2014) [6]. For instance, the employer can inspire his/her worker, telling him/her a gossip about possible future benefits of making this or that kind of job better. The worker will feel that he or she has privileges and will try to use these privileges to show his/ her best sides at work. As a result, the employer is satisfied with his/her staff, and the worker is happy, feeling that he or she is better than the others are. On the other hand, if a person hears some negative rumors about co-workers, such a person will try to work harder and look perfect at work so that not to become the next issue. Therefore, gossiping stimulates people to improve themselves and become better, which is always beneficial for the business owners.

Sometimes gossips become moral duties. For example, if a person is going to apply for a job, and his or her friends or relatives tell him/her about some positive features of the chief; it might be helpful for such person and the employer. Besides, gossip may be also a sign of friendship, which is also beneficial at work since friends can work more productively than co-workers can. For instance, two close friends like to sit together and discuss other people from their community or their personal relations with each other. Thus, they free themselves from excessive emotions and do not need to visit a psychotherapist. Moreover, while gossiping together, some new ideas can come to mind, and the employers will benefit from it. In such cases, gossips are useful and essential parts of working process and relationships between the employees. Moreover, if people exchange gossips at work, their working process becomes easier and more comfortable. 
Another benefit of negative gossip is "provide a reality check" (qtd. in Haupt) [7]. Someone in a team might face a certain problem and not be sure about its fairness. Coworkers can mildly inquire inside the team if the same issue ever occurred to them in their lives. This way it would not be fully considered as gossip, though this method has some familiar traits. However, it is a good way to get that "reality check" and worry less about the problems.

\section{The Importance of Encouraging Positive Gossiping}

In spite of advantages of gossiping, there are also those who consider gossips unnecessary and even destructive phenomena. For example, if gossips become cruel and grow into bullying or ignoring of a person under discussion, it may negatively influence that person and those who gossip. Such people will distrust their working team and will look for a job in another place (Quast, 2013) [8]. It is clear that if a person becomes an issue of rumors, and only his or her negative sides or mistakes are discussed, such a person may feel abused and offended. Thus, negative gossips may even ruin people's lives. But negative gossips about others can inspire a person to work better so that not to become a victim of rumors. Moreover, if negative rumors are stopped at once, the working atmosphere will be positive. If the workers hear only good news and pleasant information about each other, they will work more effective and productive.

DiFonzo (2011) claims that gossiping should be encouraged, due to the fact that it "signals affiliation, closeness, and camaraderie" among the employees [9]. Moreover, negative gossip serves as a useful warning about harmful people, as it is possible, for instance, to tell a new co-worker about the negative habits of the boss and thus prevent a new employee from being embroiled in troublesome situations.

Grosser, Lopez-Kidwell and Labianca [10] in their research about positive and negative gossip effect in the organizational life write about gossip being a need in the working collective in the offices of big companies with a huge number of employees. Talking behind someone's back does not sound positive, but in fact, in mostly gives a positive impact, rather than a negative one.

Schreiner says "worker's co-gossiper can serve as a sounding board, and with whom she can come to terms with the change" (Schreiner, 2016) [11]. That means that getting some sympathy through gossip from the working colleagues can be handy in the office, building trust and affection among the coworkers.

That is why it is important to encourage only positive gossips at workplaces. Gossiping helps to learn about other people's experience and use or do not use this information at work. So, one can assume that a good employer will encourage positive gossiping at work to have more efficient workers.

\section{Conclusions}

To sum it all up, it should be mentioned that gossiping is an essential part of any working process. People spread and hear gossips to satisfy their curiosity, to discuss other people's behavior, or just to chat. As a business owner, one should not 
forbid gossips at work since they are useful for stimulating workers to make their job better and improve their skills. Gossiping about other things or people, who do not work there, will be a good stimulus to relax and cheer up at work. As employers, one should encourage group interactions, such as collective celebrations of some holidays or common task for everyone. This is a good way for the employees to become closer. Constant interaction and gossips will help them to work more productively.

This research has its limitations, thus, it is needed for the subject to be developed further in order to get the full understanding of the "gossip world" within the workplace. Negative gossip effects must be studied along with the coworkers' real attitudes to it. Inquiries can be taken to get the complete conception of the subject.

The research can be useful for the employers who notice the lack of discipline or motivation at the working places. Also, if the boss wants to know something about the employees, the research can be used as a way of learning a stealthy smooth way for an employer to get to know the workers. In another way, this article can bring the positive effect which is for the workers themselves getting to know the pros and cons of the gossip and if their co-workers are gossiping around them and how to turn it to the better.

If studied by the psychologists and sociologists deeply, the article can be completed with important aspects of each science, such as human behavior traits on a different level and the society's attitude to gossip in general.

\section{References}

[1] Solomon, A. (2014) Depression Is a Disease of Loneliness. The Guardian. http://www.theguardian.com/commentisfree/2014/aug/16/depression-disease-loneli ness-friends

[2] Chua, S. and Uy, K. (2014) The Psychological Anatomy of Gossip. North American Business Press.

http://www.na-businesspress.com/AJM/ChuaS_Web14-3.pdf

[3] Prynne, M. (2014) Gossiping Benefits Society, Study Claims. The Telegraph. http://www.telegraph.co.uk/news/uknews/10601241/Gossiping-benefits-society-stu dy-claims.html

[4] Beck, J. (2014) Have You Heard? Gossip Is Actually Good and Useful. The Atlantic. http://www.theatlantic.com/health/archive/2014/11/have-you-heard-gossip-is-actua $\underline{\text { lly-good-and-useful/382430/ }}$

[5] Haupt, J. (2015) 5 Benefits of Gossip (Even Negative Gossip). Psychology Today. http://www.psychologytoday.com/blog/one-true-thing/201506/5-benefits-gossip-ev en-negative-gossip/

[6] Song, S. (2012) The Upside of Gossip: Social and Psychological Benefits. TIME.com. TIME.

http://healthland.time.com/2012/01/19/the-upside-of-gossip-social-and-psychologi cal-benefits/

[7] Zabell, S. (2014) The Surprising Upside of Office Gossip. Real Simple. http://www.realsimple.com/work-life/life-strategies/job-career/office-gossip-study

[8] Quast, L. (2013) New Managers: 5 Ways to Stop Negative Office Gossip. Forbes. 
http://www.forbes.com/sites/lisaquast/2013/10/14/new-managers-5-ways-to-stop-n egative-office-gossip/

[9] DiFonzo, N. (2011) Gossip Part 2: The Bad, the Good, and the Ugly. Psychology Today.

https://www.psychologytoday.com/blog/around-the-watercooler/201110/gossip-par t-2-the-bad-the-good-and-the-ugly

[10] Grosser, T., Lopez-Kidwell, V. and Labianca, G. (2010) A Social Network Analysis of Positive and Negative Gossip in Organizational Life. Sage Journals. http://journals.sagepub.com/doi/abs/10.1177/1059601109360391

[11] Schreiner, E. (2016) When Can Gossip in the Workplace Be Positive? The Nest. http://woman.thenest.com/can-gossip-workplace-positive-10725.html

Submit or recommend next manuscript to SCIRP and we will provide best service for you:

Accepting pre-submission inquiries through Email, Facebook, LinkedIn, Twitter, etc. A wide selection of journals (inclusive of 9 subjects, more than 200 journals)

Providing 24-hour high-quality service

User-friendly online submission system

Fair and swift peer-review system

Efficient typesetting and proofreading procedure

Display of the result of downloads and visits, as well as the number of cited articles

Maximum dissemination of your research work

Submit your manuscript at: http://papersubmission.scirp.org/

Or contact ojmp@scirp.org 